\title{
Erratum to: Expression of the Streptococcus pneumoniae yoeB Chromosomal toxin gene causes Cell Death in the model plant Arabidopsis thaliana
}

Fauziah Abu Bakar ${ }^{1}$, Chew Chieng Yeo ${ }^{2}$ and Jennifer Ann Harikrishna ${ }^{1 *}$

Following publication of our paper in BMC Biotechnology [1] we discovered that some of the images used in Figure four (Fig. 1 here) were duplicates. Because of this observation, we have made corrections to replace the duplicated images with the correct original images for Figure four B (6 dpin), Figure four C (6 dpin) and Figure four C (9dpin).

\begin{abstract}
Author details
${ }^{1}$ Centre for Research in Biotechnology for Agriculture (CEBAR) and Institute of Biological Sciences, Faculty of Science, University of Malaya, 50603 Kuala Lumpur, Malaysia. ${ }^{2}$ Biomedical Research Centre, Faculty of Medicine, Universiti Sultan Zainal Abidin, Medical Campus, 20400, Kuala Terengganu, Malaysia.
\end{abstract}

Received: 21 October 2015 Accepted: 22 October 2015

Published online: 29 October 2015

\section{Reference}

1. Abu Bakar F, Yeo CC, Harikrishna JA. Expression of the Streptococcus

pneumoniae yoeB Chromosomal toxin gene causes Cell Death in the model plant Arabidopsis thaliana. BMC Biotechnology. 2015;15:26.

\footnotetext{
* Correspondence: jennihari@um.edu.my

'Centre for Research in Biotechnology for Agriculture (CEBAR) and Institute of Biological Sciences, Faculty of Science, University of Malaya, 50603 Kuala Lumpur, Malaysia
}

Full list of author information is available at the end of the article

\section{Submit your next manuscript to BioMed Central and take full advantage of:}

- Convenient online submission

- Thorough peer review

- No space constraints or color figure charges

- Immediate publication on acceptance

- Inclusion in PubMed, CAS, Scopus and Google Scholar

- Research which is freely available for redistribution

Submit your manuscript at

www.biomedcentral.com/submit

( Biomed Central 


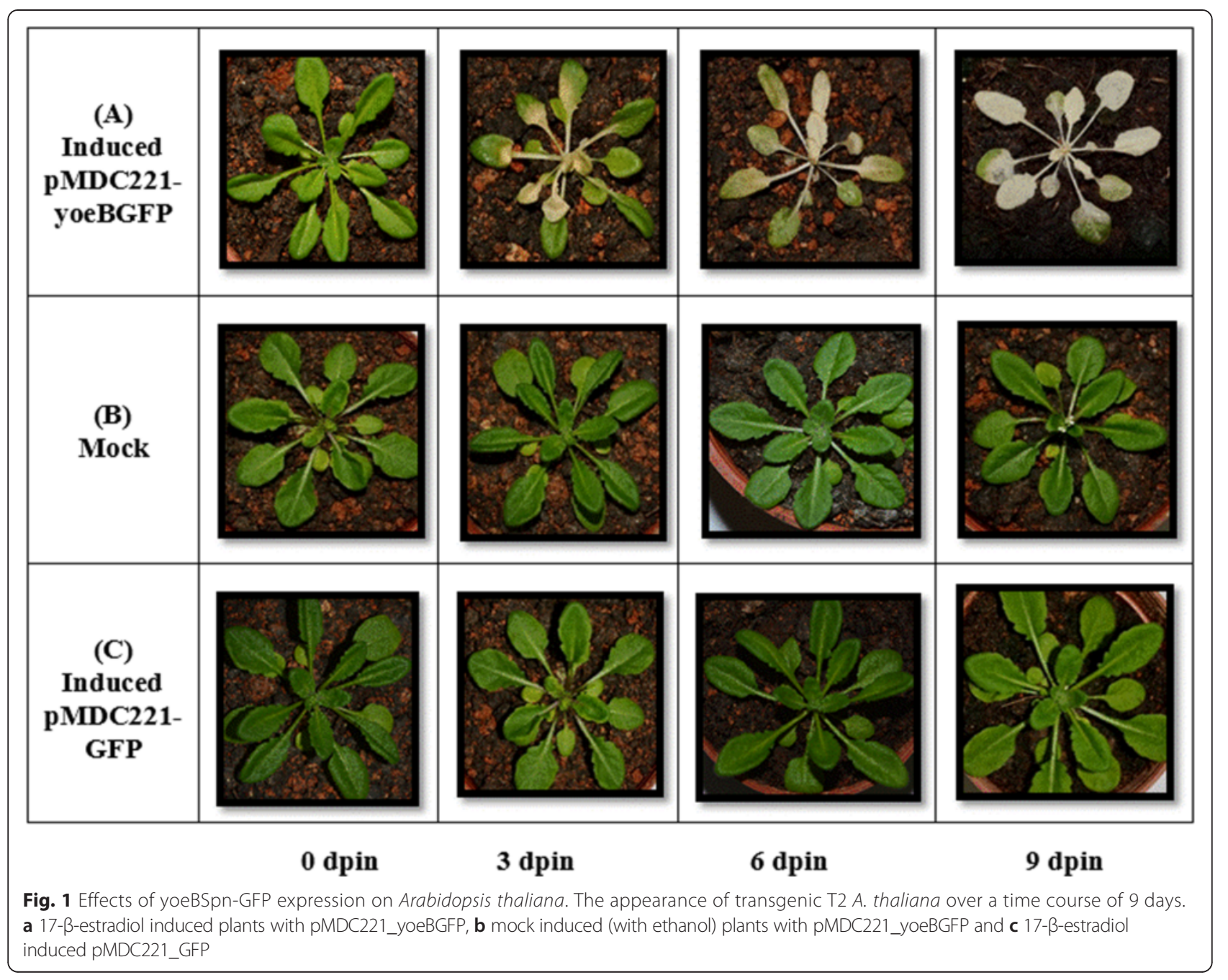

